\title{
Röntgen-Geburtshaus
}

\section{Neue Mitglieder in der Spenderfamilie}

Mit Prof. Adam (Hamburg), Prof. Diederich (Düsseldorf), Prof. Loose (Nürnberg) und PD Dr. Landwehr (Hannover) ehrte DRG-Präsident Norbert Hosten die neuen Spender des GeburtshauseS. Die Stiftung sagt Dankeschön!

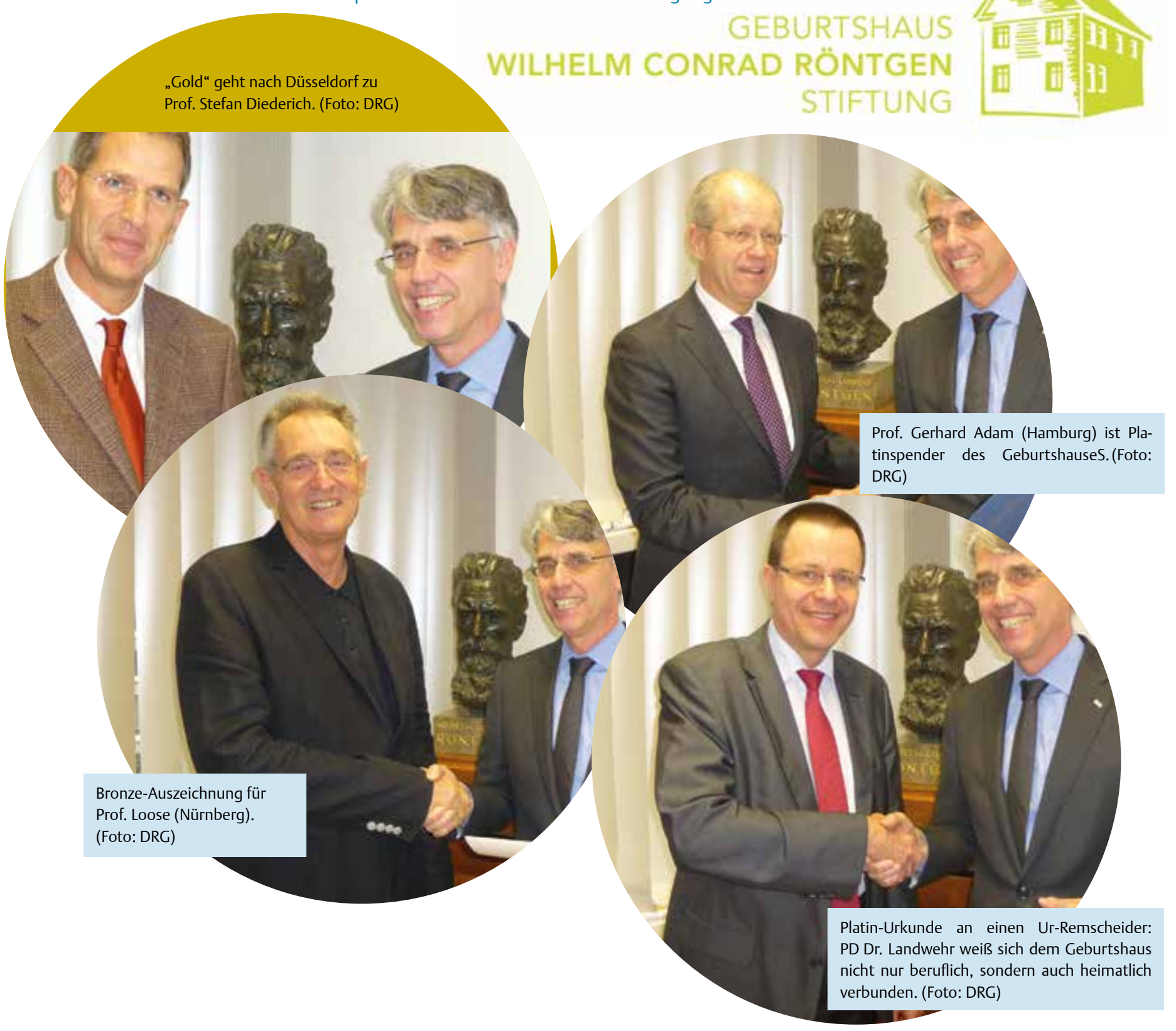

